\title{
Criminal liability as a means of counteracting sanitary and epidemiological rule violations in a pandemic
}

\author{
Andrey Vladimirovich Makarov ${ }^{1}$, Larisa Vladimirovna Makogon, Oleg Vyacheslavovich \\ Firsov, and Aleksandra Sergeevna Zhukova \\ Transbaikal State University, Department of Criminal Law and Criminal Procedure, Institute of Law, \\ Chita, Russia
}

\begin{abstract}
The purpose of the study is a comprehensive analysis of the issues of the application of criminal liability as a means of countering violations of sanitary and epidemiological rules in a pandemic. The main idea of the study: the validity and expediency of amending the criminal legislation of the Russian Federation establishing punishment for violation of sanitary and epidemiological rules and criminalization of the spread of an infectious disease. A methodological toolkit is a set of methods, means and techniques with the help of which the criminalization of violations of sanitary and epidemiological rules in a pandemic is substantiated. The following methods were used in the work: hypothetical-deductive; dogmatic (formal legal analysis); description; comparative. The result of the work is the provision that in a pandemic, a necessary condition for ensuring national security seems appropriate to criminalize the spread of infectious diseases that pose a danger to others, which will make it possible to prosecute people who, deliberately or through negligence, have committed infecting a disease included in the category of dangerous to others. These recommendations are due to the noted problems in science and practice, including the results of comparative legal analysis. The novelty of the research lies in the substantiation of amending the criminal legislation of the Russian Federation by federal law. The amendments introduce stricter types of punishments, establish responsibility for the threat of a mass disease or people intoxication, and additions have been made in the form of a third part which provides for liability for violation of sanitary standards that inadvertently entailed the death of two or more people. The peculiarities of bringing to criminal responsibility for similar acts in certain foreign countries are also considered. There is a tendency to classify such crimes as terrorism-related.
\end{abstract}

Keywords: epidemiology; responsibility; criminal law; comparative analysis

\section{Introduction}

${ }^{1}$ Corresponding author: Jus-chita@yandex.ru 
The most classical definition of a "pandemic" is given in the Great Medical Encyclopedia, where a "pandemic" (pandemia; from the Greek pandemia, i.e. the people as a whole) is an unusually strong epidemic spreading over the territory of countries, continents; it is the highest degree of development of the epidemic process [1].

For these purposes, the Federal Law of April 1, 2020 No. 100 was also prepared and adopted which amended the Criminal Code of the Russian Federation aimed at protecting citizens from the threat of the spread of infectious diseases. The provisions have significantly changed the content of Article 236 of the Criminal Code of the Russian Federation which establishes criminal liability for violation of sanitary and epidemiological rules. The legislator strengthened the punishment in Parts 1 and 2 of the specified article, included responsibility in cases of a threat of a mass disease or people intoxication, and introduced Part 3 which determines the punishment from 5 to 7 years in prison for violation of sanitary and epidemiological norms that by negligence caused the death of two or more people.

\section{Methodology}

The methodological basis of the study was the work of domestic and foreign authors, namely Gorovykh [2], Vlasenko [3], Bezverkhov, Norvartyan [4], Zhukovskaya [5], Belykh, Tarmaeva, Sirin [6], Xiang [7], Xiang [8], Chad Flanders [9], Turanjanin [10].

Gorovykh notes that "the previous version of Art. 236 of the Criminal Code of the Russian Federation was distinguished, according to its researchers, by its weak efficiency in the prevention of socially significant diseases and needed improvement" [2].

As a disadvantage, the exclusively material nature of the legislative structure of this article should be noted, since in practice it was quite difficult to establish the existence of a causal relationship between the violation of sanitary and epidemiological rules and the dangerous consequences that occurred.

Professor Luo Xiang believes that "in the joint order dated February 6, 2020 on the rules for imposing punishment for crimes against the prevention and control of new coronavirus infection which regulates that the deliberate spread of coronavirus infection should be regarded as a crime threatening public safety and qualified on the basis of crime provided by Article 114 of the Criminal Code of the People's Republic of China (imprisonment from 3 to 10 years), and Article 115 of the Criminal Code of the People's Republic of China (over 10 years of imprisonment, or life imprisonment), there are contradictions.

In his opinion, the refusal to use precautionary measures and control, which led to the spread of a new coronavirus infection, causing harm to health or death, should be recognized as the crimes threatening public safety, and not the acts violating sanitary requirements responsibility for which is provided for in Article 330 of the Criminal Code of the People's Republic of China [7]. Xiang's position is due to the lack of a unified regulatory framework.

\section{$3 \quad$ Results and discussion}

The modern understanding of the immediate object does not allow us to fully clarify the nature and degree of social danger of the encroachment, and in some cases correctly qualify the deed. In the context of Article 236 of the Criminal Code of the Russian Federation, a human disease characterized by a severe course, a high level of mortality and disability, a rapid spread among a significant number of the population in a certain territory, when the average incidence of this disease is exceeded, should be understood as a mass disease. 
It seems that the previous version of Article 236 of the Criminal Code of the Russian Federation made it possible to prosecute for this act only people who performed official or professional duties in the field of ensuring the sanitary and epidemiological well-being of the population.

In connection with the critical epidemiological situation in the country, cases of initiation of criminal cases under Part 1 of Article 236 of the Criminal Code of the Russian Federation in relation to individuals who do not possess the characteristics of a special subject. In the actions of people, they began to see signs of an act established by Article 236 of the Criminal Code of the Russian Federation in cases of violation of the self-isolation regime.

In China, in the context of a pandemic, people who were diagnosed with coronavirus or carriers of the pathogen, who refused treatment and isolation or left places of treatment without permission and visited public places or public transport, or suspected of being infected with coronavirus who refused to be isolated or treated, or who voluntarily left the place of isolation and visited public places were recognized as terrorist subjects [11].

Article 330 of the Criminal Code of the PRC regulates an act related to violation of sanitary requirements that caused the spread of an infectious disease of the first category (such as plague or cholera), or created a threat of the spread of such a disease, in violation of the Law on the Prevention of Infectious Diseases [12]. However, under Article 330 of the Criminal Code of the People's Republic of China, despite its direct purpose in the field of protecting public health, in the Order of February 6, 2020, it is proposed to qualify only cases of refusal to carry out preventive, preventive measures established by the sanitary and epidemic authorities.

Such an ambiguous approach on the part of law enforcement agencies to the practice of applying criminal norms did not go unnoticed in the scientific circles of China and remains controversial.

In the United States, there is a lack of a unified approach regarding the degree of public danger of acts violating quarantine and sanitary rules. For example, in US federal law, violation of quarantine measures does not apply to serious crimes [13]. A similar position is found in the California Legislation of Health and Safety which prescribes imprisonment in a county jail for no more than 90 days for violation of quarantine and sanitary measures [14].

However, in some states, such as Mississippi, people suffering from a dangerous infectious disease, and knowingly and willfully committing a violation of the regulations, are found guilty of a felony punishment for which can be imposed up to 5 years in prison [15].

Despite this differentiation of criminal responsibility in different states, in order to prevent and combat criminal acts that were influenced by the situation with the pandemic, the United States still strives to establish uniformity in law enforcement. The Memorandum states that the coronavirus meets the legal definition of a "biological agent" and, pursuant to Section 18, USC $\S 178$ (1), such acts are potentially terrorism-related [16].

However, according to some authors, it is inappropriate to charge such cases under the "terrorist threat" articles. In addition, the consideration of cases related to the threat of the spread of COVID-19 as a terrorist threat can cause certain difficulties in proving the presence of premeditated intent in each specific case [9].

In Denmark, a person who has allowed the spread of an infectious disease among the population or created a threat of such a situation is subject to imprisonment for a period not exceeding three years [17].

The Swedish legislator puts the spread of a serious illness on a par with such acts against life and health as poisoning or contamination of food, water, with a punishment of 
no more than six years in prison, and in the case of a serious crime, the term of imprisonment is from four to eighteen years, or life imprisonment. A crime is serious if there was intentional harm to life or health, as well as if a large number of people were exposed to danger [18].

Criminal liability for the spread of infectious diseases, according to some authors, does not always serve as a means of preventing epidemics. The reasons lie in the length of the criminal proceedings and the problems of proving the fact of transmission of an infectious disease to another person, or the circumstances of a mass illness or death of people [10].

\section{Conclusion}

Criminalization of violation of quarantine and sanitary requirements is not always recognized as the most effective criminal law measure aimed at preventing the spread of dangerous diseases, as in European countries, Norway, Denmark, etc.

Criminal liability for the spread of infectious diseases that pose a danger to others will make it possible to prosecute people who have intentionally or negligently allowed a disease that is included in the category of dangerous to others. At the same time, there will be no need to identify which sanitary and epidemiological rules were actually violated or to establish a causal relationship between the act and the resulting consequences in the form of mass disease, people intoxication or their death. The body of a crime wording can be formulated according to the principle of Article 122 of the Criminal Code of the Russian Federation, with explanations in the note that people involved in the spread of an infectious disease dangerous to others are subject to responsibility. The immediate object should be recognized as the health of an indefinite circle of people in the aspect of favourable conditions for human life excluding the possibility of harmful effects on people of environmental factors and the spread of mass infectious diseases (intoxication) among the population.

\section{References}

1. B.V. Petrovskii (ed.), Bolshaya Meditsinskaya Entsiklopediya [Great Medical Encyclopedia] (1989)

2. V.Yu. Gorovykh, Bulletin of the MGIMO-UNIVERSITY of Russian Federation, 6 , 86-89 (2010)

3. S.S. Vlasenko, Criminal Law Aspects of Counteracting the Spread of Dangerous Human Infectious Diseases (Phoenix, Rostov-on-Don, 2011)

4. A.G. Bezverkhov, Yu.S. Norvartyan, Russian Journal of Criminology, 11(3), 562-568 (2017)

5. N.Yu. Zhukovskaya, Context and Reflection: Philosophy About the World and Man, 6(3A), 48-59 (2017)

6. A.I. Belykh, I.Yu. Tarmaeva, S.A. Sirin, Sanitary offences: concept, types of responsibility, (Irkutsk State Medical University of the Ministry of Health of the Russian Federation, Irkutsk, 2017)

7. L. Xiang, He details of the rule of law. How to understand the category A infectious diseases in the crime of preventing and controlling infectious diseases? (2020). Accessed on: April 16, 2020. [Online]. Available: https://www.thepaper.cn/newsDetail_forward_5915580 
8. Z. Xiang, Journal of Wuhan University of Science and Technology. Social Science Edition, 22(2), 136-143 (2020)

9. C. Flanders, Terroristic Threats' and COVID-19: A Guide for the Perplexed, University of Pennsylvania Law Review (2020). Accessed on: April 16, 2020. [Online]. Available: https://papers.ssrn.com/sol3/ papers.cfm?abstract_id=3575700

10. V. Turanjanin, Iranian Journal of Public Health, 49(1), 4-11 (2020)

11. Notice issued by the two high-level departments on "opinions on punishing violations of the prevention and control of new coronavirus infection pneumonia epidemic", ZhengZhou University (2020). Accessed on: April 16, 2020. [Online]. Available: http://www.fao.org/faolex/results/details/en/c/LEX-FAOC194432/

12. The Supreme People's Procuratorate, Criminal law of the People's Republic of China: Section 5 Crimes against public health. Article 330 [Effective from 1 October 1997] (1997). Accessed on: April 16, 2020. [Online]. Available: http://www.spp.gov.cn/spp/fl/201802/t20180206_364975.shtml

13. Office of the law Revision Council, United States Code: Title 42, Chapter 6 A, $\S 271$ (a) Penalties for violation of quarantine law (2020). Accessed on: April 16, 2020. [Online]. Available:

https://uscode.house.Gov/view.xhtml?Path=/prelim@title42/chapter6A/subchapter2/pa rtG\&edi tion $=$ prelim

14. California legislative information, California Health and Safety Code: Chapter 4 Violations, § 120290 (2) (2017). Accessed on: April 16, 2020. [Online]. Available: https://leginfo.legislature.ca.gov/faces/codes_displayText.xhtml?lawCode=HSC\&divisi on $=105 . \&$ title $=\&$ part $=1 . \&$ chapter $=4 . \&$ article $=$

15. Lexis Nexis: Mississippi Code Public Access, Mississippi Code: Title 41, Chapter 23, $\S$ 41-23-2: [Effective from and after July 1, 1988, Current through the 2019 Regular Session] (2019). Accessed on: April 16, 2020. [Online]. Available:

https://advance.lexis.com/container?config $=00 J A A z N z h j O T Y x N C 0 w Z j R k L T Q z N z A t Y j J I Y S 1 j N j E x Z W Y x Z G F h M G Y K A F B v Z$ ENhdGFsb2cMlW40w5iIH7toHnTBIEP0\&crid=2a39f604-a7d8-42f1-bfc6-222ee1924 $7 \mathrm{bf}$

16. U.S. Department of Justice Office of the Deputy Attorney General, Memorandum for All Heads of Law Enforcement Components, Heads of Litigating Divisions, and United States Attorneys from March 24, 2020 (2020). Accessed on: April 16, 2020. [Online]. Available: https://www.justice.gov/file/1262771/download

17. Criminal Code of Denmark, Chapter 20 Offences causing danger to the Public $\S 192$ : [2005, as amended in 2015] (2015). Accessed on: April 16, 2020. [Online]. Available: http://europam.eu/data/mechanisms/PF/PF\%20Laws/Denmark/Denmark_Criminal_Co de_2005.pdf

18. The Swedish Criminal Code: Chapter 13 - On public danger offences, Section 7 [1962, amended 2020], Legislationline (2020). Accessed on: April 16, 2020. [Online].

Available:

https://www.legislationline.org/download/id/8662/file/Sweden_criminal_code_am2020 _ en.pdf 